\title{
Innovative Potential in European Countries: Analytical and Legal Aspects
}

Submitted 12/02/20, $1^{\text {st }}$ revision 02/03/20, $2^{\text {nd }}$ revision $26 / 03 / 20$, accepted $11 / 04 / 20$

\author{
S.I. Kubiv ${ }^{1}$, N.S. Bobro ${ }^{2}$, G.S. Lopushnyak ${ }^{3}$, Y.I. Lenher ${ }^{4}$, A. Kozhyna ${ }^{5}$
}

\begin{abstract}
:
Purpose: This paper aims to assess the innovation potential of Eastern European economies based on country's ability to export high-tech goods and services, which means innovating beyond the country's needs.

Design/Methodology/Approach: We use analytical economic methodology to explore innovative potential of EE (Eastern Europe) countries as correlation-regression analysis.

Findings: The study found that the innovative potential of the economy of EE (Eastern Europe) countries depends on the state's expenditures on innovative research and development, the number of scientists and the level of financing for technical cooperation.

Practical Implications: The negative factors that influence the formation of innovative potential are identified. The use of intellectual property rights by EE countries is inefficient and does not ensure the development of innovative potential. Patents for research and development of residents as well as non-residents do not ensure the progress and effectiveness of the innovative potential of the economy. The export of ICT services negatively affects innovative potential, however it is not a significant factor influencing innovative activity.

Originality/Value: With this article we show that financing technical cooperation in EE countries does not lead to the development of innovative potential, that is, it is inefficient.
\end{abstract}

Keywords: Innovative potential and capabilities, effectiveness of innovation, legal aspects.

JEL Codes: O10, O19, E22.

Paper type: Research article.

\footnotetext{
${ }^{l}$ Military Diplomatic Academy named after Yevheniy Bereznyak, Kyiv, Ukraine;

E-mail: sikubiv@ukr.net

${ }^{2}$ Institute of show business, European University, Kyiv, Ukraine;

E-mail: dir@ release-complex.com.ua

${ }^{3}$ Personnel Management and Labour Economics Department, Personnel Management,

Sociology and Psychology Faculty, Kyiv National Economic University named after Vadym

Hetman, Kyiv, Ukraine; E-mail: halstep@ukr.net

${ }^{4}$ Department of Law, Faculty of Finance, Accounting, Linguistics and Law, Lutsk National

Technical University, Lutsk, Ukraine; E-mail: lenger.yana303@gmail.com

${ }^{5}$ Department of Regional Administration, Local Self-Government and City Management,

National Academy for Public Administration under of the President Ukraine, Kyiv, Ukraine;

E-mail: akozhyna@gmail.com
} 


\section{Introduction}

The development of creative economy causes changes in approaches to the concept of innovative potential of the economy. Now, it is advisable to conduct an assessment of the country's innovative development, taking into account the state of development of the economy's creativity, that is, the number of patents, trademarks, development of information and communication services. The costs of research and development, the number of scientists are the initial factors in ensuring the innovative development of countries; however, the state of cooperation between the private, public sectors and universities, funding for technical support, and the development of skills in the innovation field are important complementary factors for the formation of innovative potential.

There is a gap among countries of Eastern Europe in terms of innovation potential, which is contingent on the basic prerequisites for its development. In particular, the countries with higher level of innovation development include the Czech Republic, Slovakia and Poland. The countries that had joined the EU were able to quickly provide the transformation of the structure of the economy. However, countries, especially those that have left the Soviet Union, are characterized by the raw material structure of the economy and the absence of effective economic policies for a long time. The data specified require studying of the formation's factors of the economies of EE countries' innovative potential.

\section{Literature Review}

European countries have introduced a linear innovation model, according to which the state obtains a leading role in its implementation (Huzair and Robbins, 2008). At the same time, innovation potential was not applied in practice for a certain period because of institutional blocking and control. EE countries are in transitional period to a free market economy; they are faced with the need to interact with new entities in the field of innovation (transnational corporations, public-private partnerships) (Robbins and Huzair, 2008; Tachmatzidi, 2019). This causes certain problems in the course of innovative development.

Stojčić, Srhoj and Coad (2020) have proven the significant influence of government financing and public procurement on the innovation capabilities of EE countries. Afandi and Kermani (2014) argue that key factors in innovative development are access to financial resources, human capital assets and the development of international trading.

Innovation is the engine of economic growth. Differences in the innovation activity of countries are determined by historical heritage, technological specialization, regional differences and peculiarities of the country (Krammer, 2009). Innovative potential is considered as a combination of various types of resources (material, financial, scientific, scientific and technical, intellectual, informational and others), 
which provide a set of opportunities for implementing measures for conducting innovative activities.

The formation of innovative potential of Eastern Europe (EE) countries remains a challenge for a long time (from the 1980s till the present time). This leads to growing scientific interest in the study of innovation development issues. After a ten-year period of transformations in EE countries (macroeconomic policies, privatization, development of institutions), the formation of innovative potential in the region remains a challenge (Radosevic and Walter, 2002).

Radosevic and Auriol (1999) have come to a conclusion that there are different levels of expenditure and employment in research and development spheres in CEE countries, which leads to their affiliation with the developed and less developed countries compared to OEEC/EU countries (Radosevic and Auriol, 1999). Stojčić, Srhoj and Coad (2020) have proven the significant impact of government's expenditure and public procurement on the innovative capabilities of EE countries. Afandi and Kermani (2014) state that access to financial resources, human capital and international trade development are key factors of innovative development.

Kravtsova and Radosevic (2012) point to the low levels of productivity in EE countries compared to existing research and development, innovation and production capacities of EE countries. Rodionova (2013) concludes that the Czech Republic, Hungary, Poland Slovenia, Estonia, Lithuania, Latvia are ahead of other EE countries in terms of innovative development, in particular due to higher ICT development. Afandi and Kermani (2014) determines firms' innovation in Eastern Europe and Central Asia. Factors for the development of innovative potential are the companies' access to financing, human capital assets and foreign trading. The study has established that innovation potential is increasing in terms of financing, a large amount of human capital assets and the attraction of foreign trading.

Krajewski (2014) notes, that the innovative potential of EE countries is still unsatisfactory and weak, with the exception of Slovenia and Estonia. Structural features of the economies of EE countries that determine innovative potential are a large share of employment in the agricultural sector, a low share of services in GDP, major portion of the so-called problem sectors of the economy, weak financial sector, low level of technical infrastructure development (Jindrichovska et al., 2020).

It has been determined in the study of Ebersberger and Mevenkamp (2016) that innovative potential is being developed due to the high level of competition, and international links of companies contribute to the development of open innovation practices.

The analysis of the literature makes it possible to identify the gap between existing studies and the research conducted. In connection with the development of ICT and the creative economy, it is advisable to assess their impact on the innovative 
potential and economic growth of the countries of Eastern Europe. The innovative potential of the economy is the country's ability to provide such a level of innovation that allows carrying out technology transfer. This means that the country's economy generates large volume of innovations for its own needs, and therefore the innovative potential is used effectively.

\section{Methodology and Data}

The United Nations' classification of the countries of Eastern Europe has been used in the study (United Nations Statistics Division), which includes: Belarus, Bulgaria, Hungary, Moldova, Poland, Russia, Romania, Slovakia, Ukraine, the Czech Republic for the period of 2011-2018 due to the availability of panel data for all countries.

The variation of the dependent variable for intragroup and intergroup regression models is estimated differently for models with panel data. When working with real panel data, there is always a problem which model (normal general regression without group effects, regression with fixed effects or regression with random effects) should be selected. In this case, a model with fixed effects was chosen because of the different level of social-economic development. Each economic unit (country) is "special" and cannot be considered as the result of a random selection from some general population. Radosevic and Auriol (1999) have noted that EE countries are characterized by different patterns of scientific-research and innovation through institutional features inherited in the central target period, general models of restructuring during the transition period and development.

For output variables (dependent, output indicators) the following factors have been selected: 1. High-technology exports, (\% of manufactured exports). 2. GDP, \% annual growth.

For input variables (independent, Input indicators) the following factors have been selected: 1. ICT service exports (\% of service exports, BoP). 2. Research and development expenditure (\% of GDP). 3. Researchers in R\&D per million people annual \% change. 4. Charges for the use of intellectual property, payments (BoP, current US\$) and defined annual \% change. 5. Charges for the use of intellectual property, receipts (BoP, current US\$) and defined annual \% change. 6. Patent applications of residents. 7. Patent applications of nonresidents. 8. Technical cooperation grants ${ }^{6}$ (BoP, current US\$) annual \% change has been identified.

\section{Results and Discussion}

\footnotetext{
${ }^{6}$ Technical cooperation grants include free-standing technical cooperation grants, which are intended to finance the transfer of technical and managerial skills or of technology for the purpose of building up general national capacity without reference to any specific investment projects.
} 
There is a rather high level of innovation potential in European countries, which is increasing every year. Analyzing the High-Tech exports of European countries in 2018, we see that the export potential of innovative technologies on average across the European Union countries is 17.9\% of exports in 2018. However, most Eastern European countries are slightly behind this indicator from other European countries (Figure 1). Gross domestic expenditure on research and development (R\&D) of European countries in 2018 averages across Europe 2.6\% in 2018 (Figure 2).

The lack of sustainable economic development in EE countries is observed: Belarus, the Czech Republic, Hungary, Moldova, Russia, Ukraine were characterized by an economic downturn for the period of 2011-2018, which was manifested in a negative value of the GDP growth rate. Bulgaria, Poland, Romania and Slovakia were able to ensure economic stability during times of global economic downturn: the annual GDP growth rate remained positive. The dependence between high-technology exports and economic growth has been shown in Figure 3. This makes it possible to identify three groups of countries in $\mathrm{EE}$ region in terms of technological development and economic growth: Ukraine, Moldova and Belarus; Poland, Slovakia, Romania, Bulgaria, Russia; Hungary and the Czech Republic.

Figure 1. High-tech exports of European countries in 2018, \% of exports

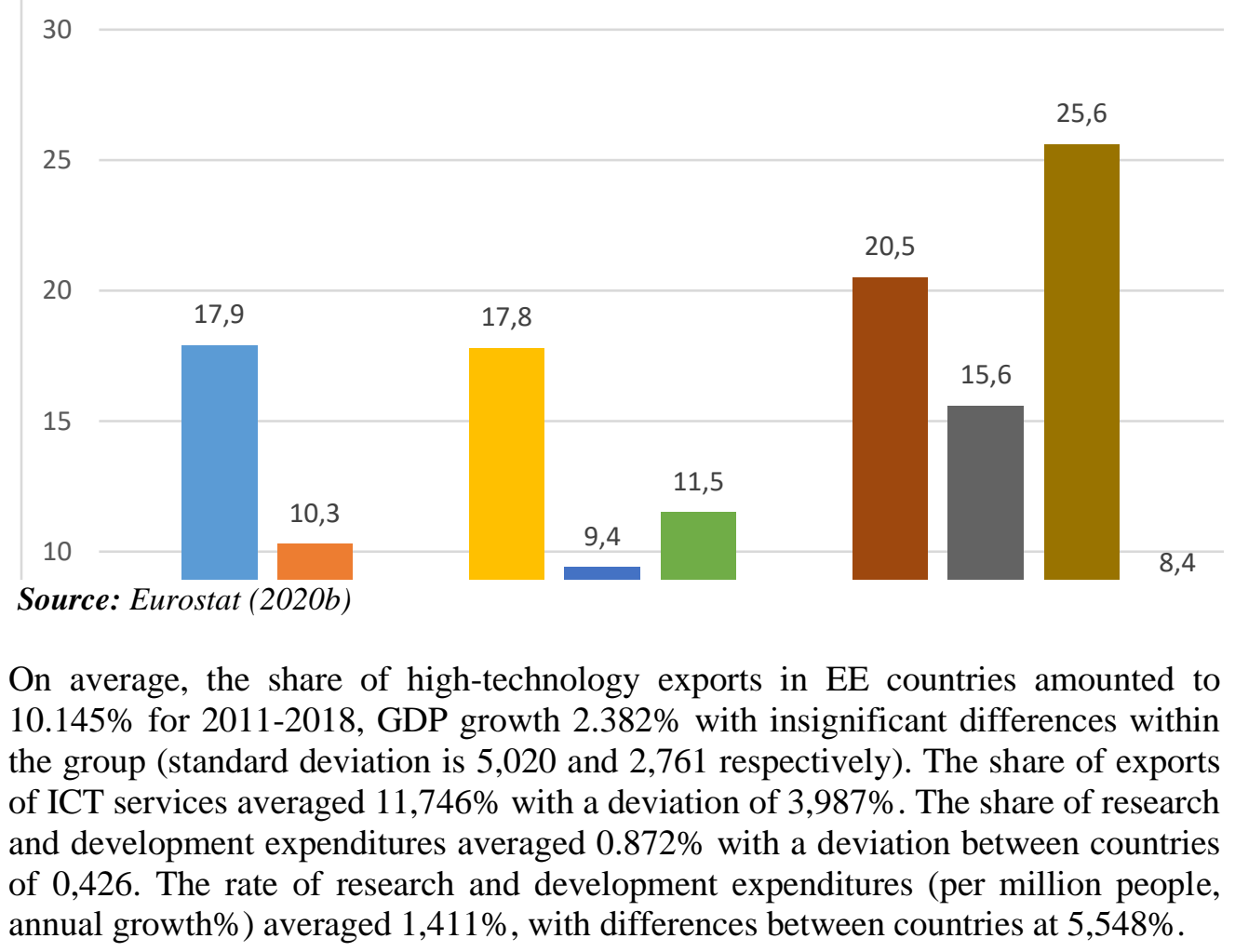


Figure 2. Gross domestic expenditure on research and development (R\&D) of European countries in 2018, \%

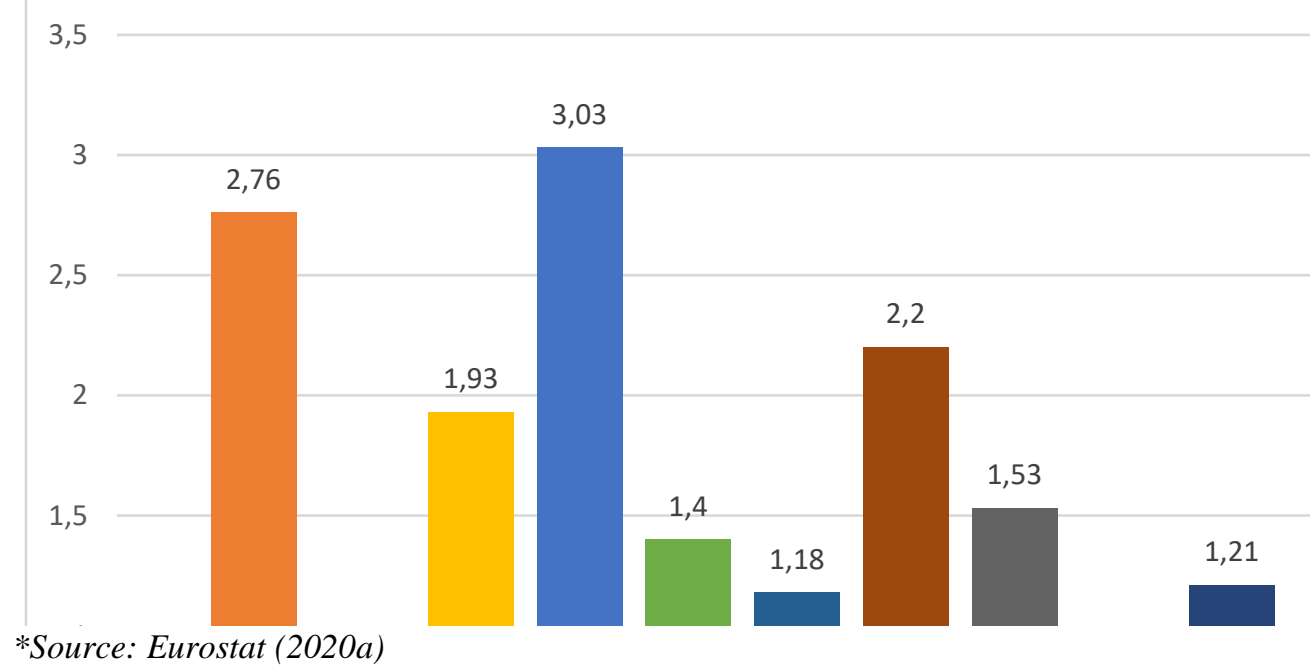

Figure 3. High-technology exports (\% of manufactured exports) and GDP growth (annual\%) in EE countries in 2018, \%

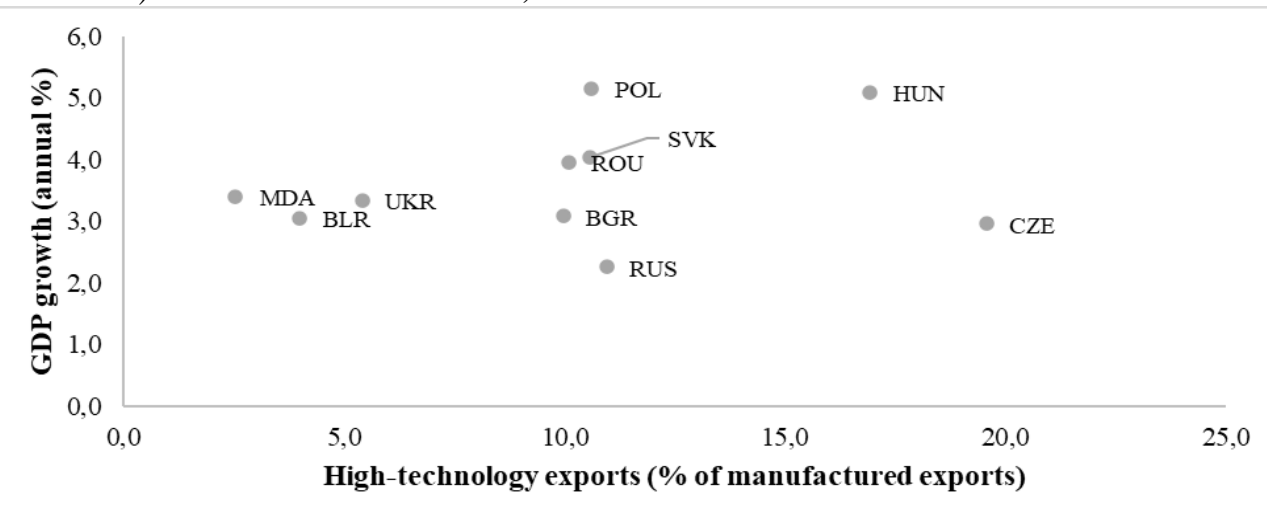

\section{Source: Eurostat (n./d.)}

The growth rate of charges for the use of intellectual property, payments averaged $9,766 \%$, due to the lack of development of the Institute of Property Rights, technology transfer. The growth rate of charges for the use of intellectual property, receipts averaged $16,200 \%$ and differed within EE countries at $68,667 \%$, which indicates significant differences among countries. Fundamental inequalities are observed in innovative development, as indicated by the average mean of patent applications by residents and non-residents: for the period of 2011-2018, 3702 and 1790 respectively with significant deviations within the group the standard deviation was 7768 and 4532 respectively. This is due to the significant advance of Poland (4207 residents' patents and 115 non-residents' patents for 2018), Romania (1100 residents' patents and 47 non-residents' patents for 2018), and the Russian 
Federation (24926 residents' patents and 13031 non-residents' patents for 2018). The annual growth rate of technical cooperation financing in EE countries amounted to $2,469 \%$ for $2011-2018$ with a deviation of $13,641 \%$. Therefore, the significant differences among the countries in the share of high-technology exports are observed, as well as in the issues of innovative development and technical cooperation financing. Such differences are, in particular, caused by various initial legal conditions for the formation of innovation potential (Table 1).

Table 1. The legal background for the formation of innovation potential of Eastern Europe countries

\begin{tabular}{|c|c|c|c|}
\hline Country & Document & $\begin{array}{l}\text { Implementation } \\
\text { period }\end{array}$ & Results \\
\hline $\begin{array}{l}\text { The Czech } \\
\text { Republic }\end{array}$ & $\begin{array}{l}\text { Innovation Strategy } \\
\text { of the Czech Republic } \\
\text { for 2019-2030 } \\
\text { (European } \\
\text { Commission, 2019) }\end{array}$ & $2020-2030$ & $\begin{array}{l}70 \text { million korunas of government } \\
\text { expenditures until } 2030,3 \% \text { expenses on } \\
\text { innovation in GDP until } 2030\end{array}$ \\
\hline Slovakia & $\begin{array}{l}\text { Strategy for Smart } \\
\text { Specialisation of the } \\
\text { Slovak Republic } \\
\text { (RIS3) (Government } \\
\text { Office of the Slovak } \\
\text { Republic, 2013) }\end{array}$ & $2013-2020$ & $\begin{array}{l}\text { The Science Agency and the Technology } \\
\text { Agency; (ii) changing shares of support } \\
\text { to basic and applied research from } \\
\text { current ratio of } 2: 1 \text { to } 1: 2 \text { by } 2020 \text {; (iii) } \\
\text { introducing 'mandatory indicator of the } \\
\text { state support to R\&D as percentage of } \\
\text { GDP in the State Budget Law', and (iv) } \\
\text { re-organising HEIs and transforming the } \\
\text { Slovak Academy of Sciences. }\end{array}$ \\
\hline Romania & $\begin{array}{l}\text { National Strategy for } \\
\text { Research, } \\
\text { Development and } \\
\text { Innovation for 2014- } \\
2020 \text { (European } \\
\text { Commission, 2014) }\end{array}$ & 2014-2020 & $\begin{array}{l}\text { Increasing the economic competitiveness } \\
\text { of the region and stimulating research } \\
\text { and innovation. Increasing accessibility } \\
\text { of the region, mobility of inhabitants, } \\
\text { goods and information. Increasing the } \\
\text { quality of life of the inhabitants of the } \\
\text { region. Protection of the natural and } \\
\text { anthropic environment, efficient use of } \\
\text { resources and reduction of polluting } \\
\text { emissions }\end{array}$ \\
\hline Ukraine & $\begin{array}{l}\text { Development strategy } \\
\text { of the sphere of } \\
\text { innovation activity for } \\
\text { the period until } 2030 \\
\text { (Legislation of } \\
\text { Ukraine, 2019) }\end{array}$ & 2019-2030 & $\begin{array}{l}\text { Development of a national innovation } \\
\text { ecosystem to ensure the rapid and high- } \\
\text { quality transformation of creative ideas } \\
\text { into innovative products and services }\end{array}$ \\
\hline Poland & $\begin{array}{l}\text { Strategy of innovation } \\
\text { and economic } \\
\text { efficiency "Dynamic } \\
\text { Poland 2020" } \\
\text { (Ministry of } \\
\text { Economy, 2013) }\end{array}$ & 2014-2020 & $\begin{array}{l}\text { Reaching the R\&D investment level of } \\
3 \% \text { of GDP }\end{array}$ \\
\hline
\end{tabular}

Source: Own. 
Eastern European countries have been improving the legal background of innovation development. The Czech Republic has adopted the "Innovation Strategy of the Czech Republic for 2019-2030”, where it has determined an increase of government expenditures on innovation in the amount of 70 million korunas over a ten-year period and achieving 3\% of GDP by 2030. During 2013-2018, Ukraine has adopted almost 40 strategic documents at the industry level relating to the development of innovation in a particular area. The Strategy for the Development of the Industrial Complex of Ukraine, the Strategy for the Development of Exports of Agricultural Products, the Food and Processing Industry of Ukraine until 2026, and the Strategy for Low Carbon Development until 2050 are being developed.

The indicators in absolute expression, selected for the construction of the models with fixed effects, are normalized by determining the growth rate of the variable (except for patent applications). Further, the data are normalized by logarithmation due to the high level of variation (more than 33\%), which could have led to unreliable results (Appendix 1). As a result, the standard error of variables is less than 1 , the average values range from -5 to +7 , indicating variation within $+/-33 \%$ (Figure 4).

Figure 4. Correlation diagram between metrics*

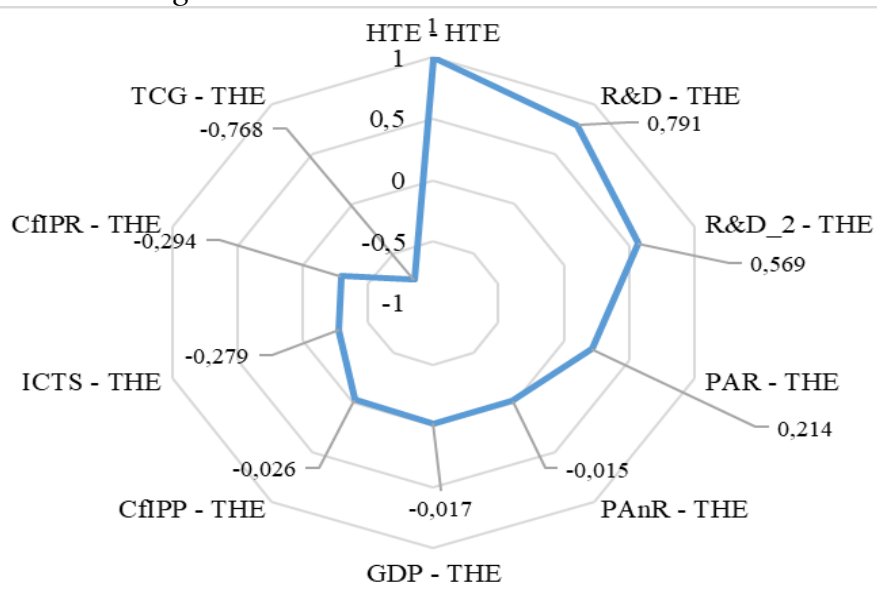

Note: The following conventional names are used: HTE - High-technology exports (\% of manufactured exports), $R \& D$ - Research and development expenditure (\% of GDP), $R \& D \_2$ - Researchers in $R \& D$ (per million people), PAR - Patent applications of residents, PAnR Patent applications of non-residents, GDP - GDP growth (annual \%), CfIPP - Charges for the use of intellectual property, payments (BoP, current US\$), ICTS - ICT service exports (\% of service exports, BoP), CfIPR - Charges for the use of intellectual property, receipts (BoP, current US\$), TCG - Technical cooperation grants (BoP, current US\$).

Source: Own.

The constructed correlation matrix (Appendix 2) indicates the feedback between many factors. The constructed correlation matrix indicates a direct relationship between: 
1. High-technology exports, research and development expenditure and researchers in R\&D and patent applications of residents. Growth in research and development expenditure and growth in the amount of researchers in R\&D provide high-tech export growth.

2. GDP growth and ICT service exports. It makes no economic sense to include factors together in an econometric intergroup model.

3. ICT service exports and technical cooperation grants. The increase in the volume of technical cooperation grants has led to an increase in the export of ICT services.

4. Research and development expenditure and researchers in $R \& D$, patent applications of residents. It makes no economic sense to include factors together in an econometric intergroup model.

5. Charges for the use of intellectual property, payments and charges for the use of intellectual property, receipts. It makes no economic sense to include factors together in an econometric intergroup model.

6. Patent applications of residents and patent applications of non-residents. It makes no economic sense to include factors together in an econometric intergroup model.

Constructed fixed effects models (Table 2) make it possible to draw conclusions about the impact of variables on the export of high-tech goods under the following conditions: 1) the model parameters are significant at $1 \%$ and $5 \%$ significance; 2 ) medium or high level of explanatory ability of the model (more than 0,2 or $20 \%$ ); the model is adequate at $1 \%$ and $5 \%$ significance. Thus, compliance with all the above conditions makes it possible to determine that models $1.2,1.3$ and 1.8 in Table 2 serve as the basis for the following conclusions:

1) government's expenditure on research and development in the countries of Eastern Europe provides an increase in the export of high-tech goods: with the significance level of $1 \%$, it can be argued that $1 \%$ increase in government's expenditure will provide an increase in the share of exports of high-tech goods by $0,859 \%$;

2) the number of researchers of scientific development is of great importance for the development of innovative potential in the countries of Eastern Europe: with the level of significance of $1 \%$ it can be argued that the growth of the number of scientists by $1 \%$ provides an increase in the share of exports of high-tech goods by $0,113 \%$;

3) the development of innovative potential is influenced by the financing of technical cooperation by the state (technical and material skills) in the countries of Eastern Europe: with the level of significance of $1 \%$, it can be argued that the volume growth of financing by $1 \%$ causes the decrease in the share of exports of high-tech goods by $-0.093 \%$. 
Table 2. Summary data of the constructed models: dependent variable hightechnology exports (\% of manufactured exports)

\begin{tabular}{|c|c|c|c|c|c|c|c|c|}
\hline \multirow[b]{2}{*}{$\begin{array}{l}\text { Independe } \\
\text { nt } \\
\text { variables }\end{array}$} & \multicolumn{8}{|c|}{ Dependent variable LN (High-technology exports) } \\
\hline & 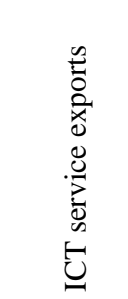 & 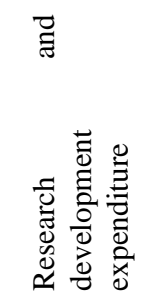 & 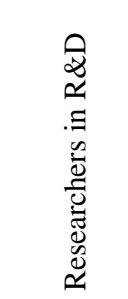 & 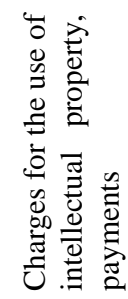 & 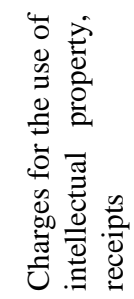 & 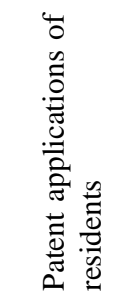 & 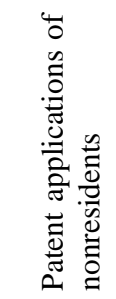 & 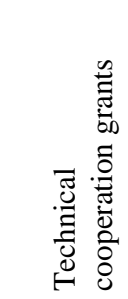 \\
\hline $\begin{array}{l}\text { Model } \\
\text { number }\end{array}$ & 1.1 & 1.2 & 1.3 & 1.4 & 1.5 & 1.6 & 1.7 & 1.8 \\
\hline Const* & 3,195 & 2,405 & 2,146 & 2,210 & 2,553 & 1,711 & 2,208 & 1,806 \\
\hline $\begin{array}{l}\text { Student's } \\
\text { t-statistic } \\
* *\end{array}$ & 8,073 & 58,809 & 43,541 & 20,335 & 17,595 & 6,728 & 14,499 & 34,413 \\
\hline p-value & 0,000 & 0,000 & 0,000 & 0,000 & 0,000 & 0,000 & 0,000 & 0,000 \\
\hline $\begin{array}{l}\text { Model } \\
\text { parameter }\end{array}$ & $-0,418$ & 0,859 & 0,113 & $-0,009$ & $-0,129$ & 0,070 & $-0,004$ & $-0,093$ \\
\hline $\begin{array}{l}\text { Student's } \\
\text { t-statistic } \\
* *\end{array}$ & $-2,567$ & 11,417 & 6,106 & $-0,227$ & $-2,720$ & 1,930 & $-0,131$ & $-10,586$ \\
\hline $\begin{array}{l}\text { Conclusio } \\
\mathrm{n} \text { on the } \\
\text { significan } \\
\text { ce of the } \\
\text { coefficien } \\
\mathrm{t}\end{array}$ & $\begin{array}{l}\text { Signific } \\
\text { ant at } \\
5 \%\end{array}$ & $\begin{array}{l}\text { Signific } \\
\text { ant at } \\
1 \%\end{array}$ & $\begin{array}{l}\text { Signific } \\
\text { ant at } \\
1 \%\end{array}$ & $\begin{array}{l}\text { Not } \\
\text { signific } \\
\text { ant }\end{array}$ & $\begin{array}{l}\text { Signific } \\
\text { ant at } \\
1 \%\end{array}$ & $\begin{array}{l}\text { Not } \\
\text { signific } \\
\text { ant }\end{array}$ & $\begin{array}{l}\text { Not } \\
\text { signific } \\
\text { ant }\end{array}$ & $\begin{array}{l}\text { Significa } \\
\text { nt at } 1 \%\end{array}$ \\
\hline p-value & 0,012 & 0,000 & 0,000 & 0,821 & 0,008 & 0,000 & 0,896 & 0,000 \\
\hline R Square & 0,078 & 0,626 & 0,323 & 0,001 & 0,087 & 0,046 & 0,000 & 0,590 \\
\hline $\begin{array}{l}\text { Conclusio } \\
\mathrm{n} \text { on the } \\
\text { level of } \\
\text { explanator } \\
y \text { ability } \\
\text { of the } \\
\text { model }\end{array}$ & Low & High & $\begin{array}{l}\text { Mediu } \\
\mathrm{m}\end{array}$ & Low & Low & Low & $\begin{array}{l}\text { Does } \\
\text { not } \\
\text { explain }\end{array}$ & High \\
\hline $\mathrm{F}$ & 6,589 & 130,340 & 37,282 & 0,052 & 7,400 & 3,726 & 0,017 & 112,055 \\
\hline $\begin{array}{l}\text { F } \\
\text { (critical) } \\
\text { at } 0,01 ; 2 ; \\
78\end{array}$ & 4,888 & 4,888 & 4,888 & 4,888 & 4,888 & 4,888 & 4,888 & 4,888 \\
\hline $\begin{array}{l}\text { F } \\
\text { (critical) } \\
\text { at } 0,05 ; 2 ; \\
78\end{array}$ & 3,114 & 3,114 & 3,114 & 3,114 & 3,114 & 3,114 & 3,114 & 3,114 \\
\hline $\begin{array}{l}\text { Significan } \\
\text { ce F }\end{array}$ & 0,012 & 0,000 & 0,000 & 0,821 & 0,008 & 0,057 & 0,896 & 0,000 \\
\hline
\end{tabular}




\begin{tabular}{|l|l|l|l|l|l|l|l|l|}
\begin{tabular}{|l|l|l|l|} 
Conclusio \\
$\mathrm{n}$ on the \\
adequacy \\
of the \\
model
\end{tabular} & $\begin{array}{l}\text { Adequat } \\
\text { e at 5\% }\end{array}$ & $\begin{array}{l}\text { Adequa } \\
\text { te at } \\
\mathbf{5 \%}\end{array}$ & $\begin{array}{l}\text { Adequa } \\
\text { te at 5\% }\end{array}$ & $\begin{array}{l}\text { Not } \\
\text { adequat } \\
\text { e }\end{array}$ & $\begin{array}{l}\text { Adequa } \\
\text { te at 1\% }\end{array}$ & $\begin{array}{l}\text { Adequa } \\
\text { te at } \\
5 \%\end{array}$ & $\begin{array}{l}\text { Not } \\
\text { adequa } \\
\text { te }\end{array}$ & $\begin{array}{l}\text { Adequat } \\
\text { e at 1\% }\end{array}$ \\
\hline $\begin{array}{l}\mathrm{t} \text { critical } \\
\text { at } \quad(0,01 ; \\
78)\end{array}$ & 2,640 & 2,640 & 2,640 & 2,640 & 2,640 & 2,640 & 2,640 & 2,640 \\
\hline $\begin{array}{l}\mathrm{t} \quad \text { critical } \\
\text { at } \quad(0,05 ; \\
78)\end{array}$ & 1,991 & 1,991 & 1,991 & 1,991 & 1,991 & 1,991 & 1,991 & 1,991 \\
\hline $\begin{array}{l}\text { Number } \\
\text { of } \\
\text { observatio } \\
\text { ns }\end{array}$ & 80 & 80 & 80 & 80 & 80 & 80 & 80 & 80 \\
\hline
\end{tabular}

Note: *-coefficient (model parameter), constant

** - Student's t-statistic for parameter significance estimation, $F$ - Fisher's criterion, $p$ value - parameter significance level (1\%, 5\%).

Source: Own.

\section{Conclusion}

Such conclusions and modeling results confirm that the innovative potential of EE countries does not ensure economic growth, and, as noted by Kravtsova and Radosevic (2012), they are provided with production. Financing of technical cooperation in EE countries does not lead to the development of innovative potential. On the other hand, EE countries can generate innovative potential through financing of research and development, stimulating an increase in the number of scientists.

The study by Pegkas, Staikouras and Tsamadias (2019) proves the co-integration relationship between innovation and research and development expenditures. As Gál and Páger (2017) state, "innovation in EE countries is negatively linked to the migration of skilled and qualified graduates". Such dependence has been also revealed in the study of Stojčić, Srhoj and Coad (2020). The authors prove the impact of government's expenditure and procurement on innovation level in EE countries: the highest level of efficiency is achieved precisely through the combination of two forms of state regulation. At the same time, Högselius (2017) states that research and development are ineffective in the development of innovation in EE countries. The use of intellectual property rights in EE countries is inefficient and does not support the development of innovative potential. This may mean insufficient level of protection of intellectual property rights, adverse business climate of EE countries. As Krammer (2009) proves, these factors contribute to patenting and the emergence of further innovations. Our study indicates that patents for research and development by residents and non-residents do not ensure the development and efficiency of the innovative potential of the economy. This may be due to the low quality of research and development in the countries of Eastern Europe. Krammer (2009) proves that universities, existing national knowledge base, 
developed private and public cooperation play a key role in the effectiveness of using innovative potential.

Similar conclusions are confirmed in the study of Horbach (2016). Eco-innovations in the countries of Eastern Europe are particularly dependent on government regulation and grants. However, an analysis of our study indicates an increase in subsidies by the governments of $\mathrm{EE}$ countries towards financing technical cooperation (skills), while expenditure should be directed to the very developments. Eastern European firms are particularly reliant on external R\&D activities, indicating the transfer of technology from West to East (Horbach, 2016). There is a controversial opinion of one scholar (Högselius, 2017), according to which the dynamics of innovations in post-communist countries should not be primarily considered as a "transfer" of Western technologies, innovative practices and the structure of innovations to EE countries. Conclusion of Horbach (2016) correlates with our study and confirms the ineffectiveness of patents for generating innovative potential in EE countries.

The export of ICT services negatively affects the innovative potential, however, it is a minor factor of influence on the innovative activity of EE countries (low explanatory ability of the model). The conclusion has been made in the study of Rodionova (2013) that there is a gap between the development of ICT in EE and CIS countries. Herewith, the countries of Eastern and Central Europe accelerated the pace of transition to a knowledge economy to compare with Russia and other EE countries.

\section{References:}

Afandi, E., Kermani, M. 2014. What determines firms' innovation in Eastern Europe and Central Asia. Perspectives of Innovations, Economics and Business, 14(1), 1-20. https://doi.org/10.15208/pieb.2014.01.

Ebersberger, B., Mevenkamp, N. 2016. Open Innovation in Eastern Europe and Central Asia. Journal of Business Administration Research, 5(2), 8-19.

European Commission. 2014. National Strategy for Research, Development and Innovation 2014-2020. Available at: https://ec.europa.eu/growth/tools-databases/regionalinnovation-monitor/policy-document/macroregiunea-doi/national-strategy-researchdevelopment-and-innovation-2014-2020.

European Commission. 2019. Innovation Strategy of the Czech Republic 2019-2030. Available at: https://ec.europa.eu/growth/tools-databases/regional-innovationmonitor/policy-document/česko/innovation-strategy-czech-republic-2019---2030.

Eurostat. 2020a. Gross domestic expenditure on research and development (R\&D). Available at: https://ec.europa.eu/eurostat/databrowser/view/tipsst10/default/table?lang=en.

Eurostat. 2020b. High-tech exports. Available at: https://ec.europa.eu/eurostat/databrowser/view/tin00140/default/table?lang=en.

Gál, Z., Páger, B. 2017. The changing role of universities and the innovation performance of regions in Central and Eastern Europe. The Routledge Handbook to Regional Development in Central and Eastern Europe, 2, 225-239. 
Government Office of the Slovak Republic. 2013. RIS3 - Research and Innovation Strategy for Smart Specialization. Available at: https://www.eu2020.gov.sk//ris3-strategiavyskumu-a-inovacii-pre-inteligentnu-specializaciu/.

Högselius, P. 2017. The Dynamics of Innovation in Post-Communist Countries: Opportunities and Challenges. Industries and Markets in Central and Eastern Europe, 4, 85-104.

Horbach, J. 2016. Empirical determinants of eco-innovation in European countries using the community innovation survey. Environmental Innovation and Societal Transitions, $19,1-14$.

Huzair, F., Robbins, P. 2008. Life Sciences Innovation in Central and Eastern Europe: Conceptual Frameworks and Contributions. Studies in Ethics, Law, and Technology, 2(2). https://doi.org/10.2202/1941-6008.1053.

Jindrichovska, I., Ugurlu, E., Thalassinos, I.E. 2020. Exploring the Trend of Czech FDIs and their Effect to Institutional Environment. International Journal of Economics and Business Administration, 8(1), 94-108. DOI: 10.35808/ijeba/411.

Krajewski, S. 2014. Innovation Levels in the Economies of Central and Eastern Europe. Comparative Economic Research, 17(3), 101-122.

Krammer, S.M. 2009. Drivers of national innovation in transition: Evidence from a panel of Eastern European countries. Research Policy, 38(5), 845-860.

Kravtsova, V., Radosevic, S. 2012. Are Systems of Innovation in Eastern Europe Efficient? Economic Systems, 36(1), 109-126. https://doi.org/10.1016/j.ecosys.2011.04.005.

Legislation of Ukraine. 2019. Decree: On approval of the Strategy for development of the sphere of innovative activity for the period till 2030. Available at: https://zakon.rada.gov.ua/laws/show/526-2019-p.

Ministry of Economy. 2013. Strategy for Innovation and Efficiency of the Economy: Dynamic Poland 2020. Ministry of Economy, Warsaw.

Pegkas, P., Staikouras, C., Tsamadias, C. 2019. Does research and development expenditure impact innovation? Evidence from the European Union countries. Journal of Policy Modeling, 41(5), 1005-1025. https://doi.org/10.1016/j.jpolmod.2019.07.001.

Radosevic, S., Auriol, L. 1999. Patterns of restructuring in research, development and innovation activities in central and eastern European countries: an analysis based on S\&T indicators. Research Policy, 28(4), 351-376.

Radosevic, S., Walter, G.H. 2002. Supporting Innovation Through Institution Building in Central and Eastern Europe: Between Visions and Realitie. Small Firms and Entrepreneurship in Central and Eastern Europe, 3, 213-235.

Robbins, P., Huzair, F. 2008. Innovation in Central and Eastern Europe: An Editorial. Studies in Ethics, Law, and Technology, 2(2). doi:10.2202/1941-6008.1058.

Rodionova, I. 2013. Competitiveness of Countries in the World Innovation Economy: Central-Eastern Europe and Russia. Quaestiones Geographicae, 32(2), 15-24. https://doi.org/10.2478/quageo-2013-0010.

Stojčić, N., Srhoj, S., Coad, A. 2020. Innovation procurement as capability-building: Evaluating innovation policies in eight Central and Eastern European countries. European Economic Review, 121, 103-330. https://doi.org/10.1016/j.euroecorev.2019.103330.

Tachmatzidi, I. 2019. Comparative Analysis of Takeover Defenses in Strong and Weak Economies: The Paradigm of the UK and Greece. European Research Studies Journal, 22(2), 254-264.

Thalassinos, I.E., Thalassinos, E.P., Venedictova, B., Yordanov, V. 2015. Currency Board Arrangement Capital Structure Macro-Financial Diagnostic. SSRN-id2624333.pdf. 
Appendix 1: Descriptive statistics of variables

\begin{tabular}{|c|c|c|c|c|c|c|c|c|c|c|}
\hline & 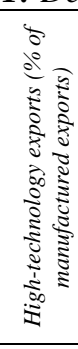 & 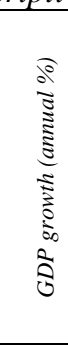 & 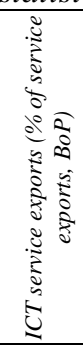 & 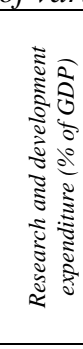 & 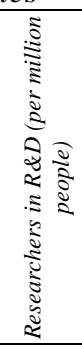 & 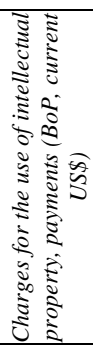 & 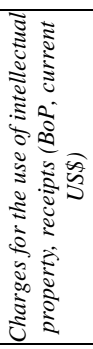 & 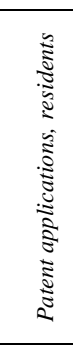 & 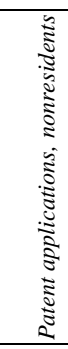 & 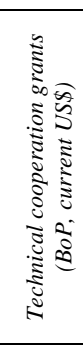 \\
\hline Mean & 2,189 & 0,824 & 2,404 & $-0,251$ & 0,386 & 2,343 & 2,822 & 6,815 & 4,890 & $-4,113$ \\
\hline $\begin{array}{l}\text { Standard } \\
\text { Error }\end{array}$ & 0,059 & 0,115 & 0,039 & 0,054 & 0,295 & 0,171 & 0,135 & 0,179 & 0,232 & 0,485 \\
\hline Median & 2,248 & 1,098 & 2,393 & $-0,242$ & 1,381 & 2,608 & 2,956 & 6,676 & 4,233 & $-6,908$ \\
\hline Mode & 2,861 & $\# \mathrm{n} / \mathrm{a}$ & $\# \#$ n/a & $-0,260$ & $\begin{array}{c}- \\
6,908 \\
\end{array}$ & $\# \#$ n/a & $\# \#$ n/a & 4,205 & 4,190 & $-6,908$ \\
\hline $\begin{array}{c}\text { Standard } \\
\text { Deviatio } \\
\text { n }\end{array}$ & 0,527 & 1,028 & 0,352 & 0,485 & 2,642 & 1,533 & 1,204 & 1,603 & 2,079 & 4,338 \\
\hline $\begin{array}{c}\text { Sample } \\
\text { Variance }\end{array}$ & 0,277 & 1,057 & 0,124 & 0,235 & 6,983 & 2,350 & 1,450 & 2,571 & 4,323 & 18,822 \\
\hline
\end{tabular}

Appendix 2: Correlation matrix of variables

\begin{tabular}{|c|c|c|c|c|c|c|c|c|c|c|}
\hline & 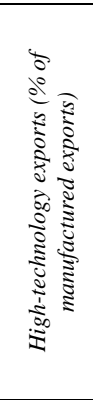 & 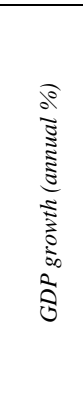 & 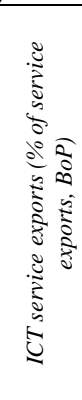 & 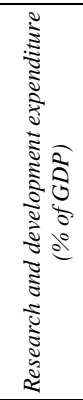 & 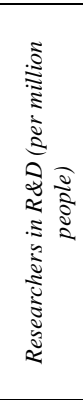 & 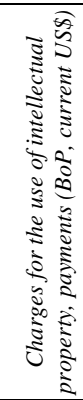 & 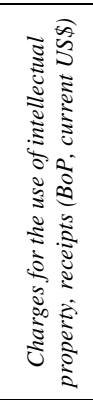 & 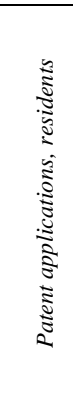 & 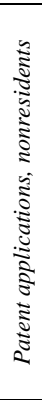 & 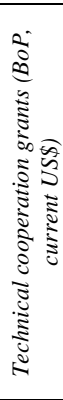 \\
\hline $\begin{array}{l}\text { High-technology } \\
\text { exports (\% of } \\
\text { manufactured } \\
\text { exports) }\end{array}$ & 1,000 & & & & & & & & & \\
\hline $\begin{array}{l}\text { GDP growth } \\
(\text { annual \%) }\end{array}$ & $-0,017$ & 1,000 & & & & & & & & \\
\hline $\begin{array}{l}\text { ICT service exports } \\
(\% \text { of service } \\
\text { exports, BoP) } \\
\end{array}$ & $-0,279$ & 0,237 & 1,000 & & & & & & & \\
\hline $\begin{array}{c}\text { Research and } \\
\text { development } \\
\text { expenditure (\% of } \\
\text { GDP) } \\
\end{array}$ & 0,791 & $-0,063$ & $-0,530$ & 1,000 & & & & & & \\
\hline $\begin{array}{c}\text { Researchers in } \\
\text { R\&D (per million } \\
\text { people) }\end{array}$ & 0,569 & $-0,024$ & $-0,108$ & 0,273 & 1,000 & & & & & \\
\hline $\begin{array}{l}\text { Charges for the use } \\
\text { of intellectual } \\
\text { property, payments } \\
\text { (BoP, current US\$) }\end{array}$ & $-0,026$ & $-0,131$ & $-0,069$ & 0,061 & $-0,156$ & 1,000 & & & & \\
\hline $\begin{array}{l}\text { Charges for the use } \\
\text { of intellectual } \\
\text { property, receipts } \\
\text { (BoP, current US\$) }\end{array}$ & $-0,294$ & $-0,165$ & 0,094 & $-0,270$ & $-0,100$ & 0,215 & 1,000 & & & \\
\hline $\begin{array}{c}\text { Patent applications, } \\
\text { residents }\end{array}$ & 0,214 & $-0,067$ & $-0,508$ & 0,351 & 0,053 & $-0,046$ & $-0,065$ & 1,000 & & \\
\hline
\end{tabular}


Innovative Potential in European Countries: Analytical and Legal Aspects 264

\begin{tabular}{|c|c|c|c|c|c|c|c|c|c|c|}
$\begin{array}{c}\text { Patent applications, } \\
\text { nonresidents }\end{array}$ & $-0,015$ & $-0,122$ & $-0,414$ & 0,136 & $-0,032$ & $-0,076$ & $-0,017$ & 0,859 & 1,000 & \\
\hline $\begin{array}{c}\text { Technical } \\
\text { cooperation grants } \\
\text { (BoP, current US\$) }\end{array}$ & $-0,768$ & $-0,002$ & 0,352 & $-0,602$ & $-0,541$ & $-0,020$ & 0,116 & $-0,226$ & 0,131 & 1,000 \\
\hline
\end{tabular}

